\title{
Long-term study of the immuno-pathological consequences of sympathetic orchiopathia in the rat
}

\author{
D. I. Lewis-Jones, R. V. Lynch, D. D. Kerrigan and I. Davies \\ Department of Human Anatomy and Cell Biology, University of Liverpool, \\ Liverpool L69 $3 B X, U . K$.
}

\begin{abstract}
Summary. Unilateral testicular ischaemia was induced in Wistar rats by ligation and division of the testicular and deferential vessels. Damage (as assessed by a Johnsen count) to the contralateral testis caused significant spermatogenic suppression only at the equator of the testis at 28 days after operation. Cytotoxic antisperm antibody production increased progressively from 7 to 14 days and became maximal at 28 days after infarction, but after 3 and 6 months antibody production was decreasing. The presence of agglutinating antisperm antibody was noted at 28 days, 3 months and 6 months after infarction. Serum immunoglobulin estimations revealed an increase in IgG and IgM levels at 7 days and IgM levels at 14 days, supporting the contention that an immunological reaction had occurred.

It is suggested that unilateral testicular ischaemia in the rat, an animal model intended to mimic torsion of the testis in the human, causes a transient immunological phenomenon (sympathetic orchiopathia) which recovers over the course of time. Caution should be exercised before regarding this relatively common surgical emergency as an aetiology of oligospermia or asthenospermia.
\end{abstract}

\section{Introduction}

The contents of the male reproductive tract are highly antigenic. Gametic antigens include spermatozoa, germ cells and seminal plasma components (Hjort, 1983). The 'blood-testis' barrier, comprising tight junctions between cells in the membrana propria of the seminiferous tubule and between adjacent Sertoli cells within the tubule, normally sequesters gametic antigen from the immune system (Setchell \& Waites, 1975). The mechanisms which prevent the formation of antibodies against spermatozoa within the ductus epididymidis are unknown. It has been suggested that immunocompetent cells within the epididymis, probably lymphocytes, are responsible (de Kretser et al., 1982; Ritchie et al., 1984; El-Demiry et al., 1985).

Unilateral testicular infarction in the rat provides a model for the study of the infertility, or subfertility, which can follow testicular ischaemia associated with torsion of the testis in the human. Previous work has shown that unilateral testicular ischaemia in the rat achieved either by twisting or ligation and division of the blood supply, causes contralateral testicular damage. This has been demonstrated at both light and electron microscopic levels after variable periods of ipsilateral testicular infarction, ranging from 7 days to 8 weeks (Lewis-Jones et al., 1982; Wallace et al., 1982; Nagler \& White, 1982; Williamson \& Thomas, 1984; Cosentino et al., 1985; York \& Drago, 1985). The phenomenon has been named sympathetic orchiopathia and, because no inflammatory reaction in the contralateral testis has been demonstrated, an autoimmune aetiology has been suggested (Wallace et al., 1982). This contention has been supported by increases in serum cytotoxic antisperm antibody in rats undergoing unilateral testicular infarction for 7-28 days as well as immunoglobulin within their contralateral seminiferous tubules apparently breaching the bloodtestis barrier (Lewis-Jones et al., 1982; Thomas et al., 1984; Lewis-Jones et al., 1987). Antibody was 
detected within the supportive cells of the seminiferous tubule, the Sertoli cells, and also within immature spermatogenic cells, i.e. spermatogonia and primary spermatocytes. It has been suggested that the invading antibody, apparently an antitestis antibody, is responsible for contralateral testicular damage in sympathetic orchiopathia, but at no time has cell-mediated damage to the blood-testes barrier been demonstrated. After 28 days no significant amounts of antibody have been demonstrated within contralateral seminiferous tubules. These immunocytochemical findings were not confirmed by Wallace et al. (1982) although different experimental techniques were used.

Contralateral testicular damage has also been demonstrated in rabbits after unilateral testicular torsion, but not subsequent to complete ligation of the ipsilateral testicular blood supply (Cerasaro et al., 1984). In the rabbit, some degree of circulation to the infarcted testis is necessary to trigger the autoimmune damage. Unlike the rat, no significant antisperm antibody production was observed when compared to controls, but the method used for detection of antibody was an enzyme-linked immunosorbant assay not used in other investigations. It was therefore suggested that antibody directed against spermatozoa might not be the agent causing morphological damage in the testis.

Subsequent studies, including detorsion of the ipsilateral testis after various periods of ischaemia, orchidectomy of the infarcted testis and immunosuppression, have shown that contralateral testicular damage can be reduced or prevented dependent on the timing of further treatment (Nagler \& White, 1982; Thomas et al., 1984; Cosentino et al., 1985; Kearney \& Lewis-Jones, 1985; York \& Drago, 1985).

The aims of the present study with rats were (i) to consider the long-term effects of continued unilateral testicular ischaemia upon testicular morphology and spermatogenesis, and (ii) to identify any continuing immune response, as indicated by increases in one, or more, serum immunoglobulin classes, or by an increase in the concentration of serum cytotoxic antisperm antibody.

\section{Materials and Methods}

Animals. Sexually mature albino male Wistar rats, weighing 250-350 g, were selected and allocated to three groups (A, $\mathrm{B}$ and $\mathrm{C}$ ). Each group contained one of three inbred littermates, and there were 10 animals in each group for each time interval studied. Five time intervals were considered after the induction of unilateral testicular ischaemia, i.e. the series comprised 150 animals.

Group A rats were anaesthetized with ether, the abdominal cavity was opened, and the vascular bundle to the right testis was ligated with two silk $5 / 0$ sutures and then divided above its anastomosis with the deferential vessel. A vasectomy was also performed to ligate the vessels running with the vas deferens. Any other small vessels supplying the testis or epididymis were also divided.

Group B rats were also anaesthetized with ether and the abdominal cavity opened. The vascular supply to the right testis and the vas deferens were isolated and manipulated, but the blood supply was not interrupted.

Group $\mathrm{C}$ animals acted as unoperated controls.

At the predetermined times, animals were deeply anaesthetized with pentobarbitone sodium and, after removal of blood by cardiac puncture, fixed by total body perfusion with Bouin's fixative at $140 \mathrm{mmHg}$. Contralateral (i.e. the left) testes were removed from animals in all groups and 3-4 mm slices were taken from the equatorial and rete testis regions. The slices were post-fixed by immersion in Bouin's solution for $12 \mathrm{~h}$ and then embedded in paraffin wax.

Histological assessment. Slices from the equatorial and rete testis regions were sectioned at $8 \mu \mathrm{m}$, at least four sections being taken from each region. Sections were stained with haematoxylin and eosin, and a modified Johnsen count (Johnsen, 1970; Lewis-Jones \& Kerrigan, 1985) was performed on each section; a minimum of 200 seminiferous tubules was examined on each section and graded out of 10 as to their stage of spermatogenesis (for which a score of 10 indicates normal spermatogenesis, and a score of 1 indicates no spermatogenic cells in tubular section).

Cytotoxic antisperm antibody test. Heat-inactivated serum from all animals was serially diluted in two volumes of diluent (47\% Hanks Balanced Salt Solution; Gibco Limited, Paisley, U.K.; and 5.3\% heat-inactivated fetal calf serum; Sera-lab, Crawley Down, Sussex, U.K.). One volume of complement (guinea-pig serum absorbed with rat spermatozoa and diluted 1 in 5) was added to each dilution. The solutions were warmed in a water bath to $37^{\circ} \mathrm{C}$ and one volume of normal rat spermatozoa (obtained from the epididymal tail of rats from the same inbred stock) was added to each dilution. The dilutions were incubated at $37^{\circ} \mathrm{C}$ for $15 \mathrm{~min}$ and then scored for the percentage of dead spermatozoa evaluated by eosin penetration (Boyce et al., 1964). The cytotoxic effect of serum without complement, complement without serum, and diluent alone, upon the same normal rat spermatozoa represented controls. 
Agglutinating antisperm antibody test. The micro-tray agglutination test (Friberg, 1974) was performed on all sera from all animals at each time. Due to the inherent cytotoxicity of control serum, it was necessary to perform the test with serum dilutions of $>1 / 96$ to ensure sufficient sperm motility for agglutination. Phosphate-buffered saline (PBS) was used for dilution of serum: $5 \mu$ of each serum sample were transferred to disposable Hamex micro-agglutination chambers (Medicell International, London, U.K.) under liquid paraffin and $1 \mu$ of the donor sperm suspension was subsequently added (suspensions of spermatozoa used in this test had concentrations of $20 \times 10^{6} / \mathrm{ml}$ in the same diluent as used for the cytotoxic test). After $4 \mathrm{~h}$ the trays were examined with an inverted Nikon (Diaphot-TMD) microscope $(\times 100$ and $\times 600)$ for evidence of sperm agglutination. If all spermatozoa were agglutinated the test was scored $3+$, large agglutinates scored $2+$ and small scattered agglutinates scored $1+$.

Serum immunoglobulin assay. The concentrations of IgM, IgG and IgA in the serum samples from all animals were measured by single radial immunodiffusion (Mancini et al., 1965). Samples were tested in duplicate on each of two separate immunodiffusion plates at three different dilutions. Goat antisera to IgA and IgM, and a rabbit antiserum to IgG (Nordic Immunological Laboratories, Maidenhead, Berks, U.K.) were used. A rat reference serum (Serotec, Bicester, Oxon, U.K.) was used as a standard for IgA and IgM, and purified rat IgG standard (Sigma Chemicals, Poole, Dorset, U.K.) was used for IgG estimations.

Table 1. Mean ( \pm s.d.) Johnsen count in rats in Groups $A, B$ and $C$ from the rete testis and equatorial regions of the testis at the five experimental times

\begin{tabular}{|c|c|c|c|c|c|c|}
\hline \multirow[b]{2}{*}{ Time } & \multicolumn{2}{|c|}{$\begin{array}{l}\text { Group A } \\
\text { (ligated) }\end{array}$} & \multicolumn{2}{|c|}{$\begin{array}{c}\text { Group B } \\
\text { (sham-operated) }\end{array}$} & \multicolumn{2}{|c|}{$\begin{array}{c}\text { Group C } \\
\text { (unoperated) }\end{array}$} \\
\hline & Equator & Rete & Equator & Rete & Equator & Rete \\
\hline 7 days & $8 \cdot 20 \pm 0 \cdot 11$ & $8 \cdot 24 \pm 0 \cdot 16$ & $8 \cdot 22 \pm 0 \cdot 11$ & $8 \cdot 32 \pm 0 \cdot 17$ & $8 \cdot 25 \pm 0.15$ & $8 \cdot 26 \pm 0 \cdot 12$ \\
\hline 14 days & $8 \cdot 20 \pm 0 \cdot 12$ & $8.21 \pm 0.09$ & $8.31 \pm 0.08$ & $8 \cdot 29 \pm 0 \cdot 10$ & $8 \cdot 24 \pm 0.09$ & $8.26 \pm 0.13$ \\
\hline 28 days & $8 \cdot 19 \pm 0 \cdot 11^{*}$ & $8.20 \pm 0.05$ & $8.29 \pm 0.07$ & $8 \cdot 24 \pm 0 \cdot 10$ & $8.30 \pm 0.06$ & $8.22 \pm 0.11$ \\
\hline 3 months & $8 \cdot 30 \pm 0 \cdot 17$ & $8 \cdot 22 \pm 0.14$ & $8.21 \pm 0.09$ & $8 \cdot 30 \pm 0 \cdot 10$ & $8 \cdot 20 \pm 0.07$ & $8 \cdot 21 \pm 0.11$ \\
\hline 6 months & $8 \cdot 24 \pm 0.12$ & $8.28 \pm 0.07$ & $8.32 \pm 0.08$ & $8.29 \pm 0.08$ & $8.19 \pm 0.08$ & $8.26 \pm 0.09$ \\
\hline
\end{tabular}

${ }^{*} P<0.05$ compared with values for Group B and Group C (Student's paired $t$ test and Wilcoxon signed rank test).

\section{Results}

\section{Histological assessment}

Johnsen counts in the various groups (Table 1) were analysed statistically using Student's paired $t$ test and the Wilcoxon Signed Rank test. A significant suppression of spermatogenesis was only observed at 28 days, in Group A rats, and then only in the equatorial region of the testis.

\section{Cytoxic antisperm antibody test}

The results shown in Table 2 demonstrate that the cytotoxicity of sera from the Group A animals was significantly greater than that from the two control groups (Groups B and C) at all three dilutions tested and for each time $(P<0.05$; Student's $t$ test). There was no significant difference in the cytotoxicity of sera from the two control groups (Groups B and C). When sera from Group A animals were tested without complement, the cytotoxicity was not significantly different from that of the two control groups.

In the Group A animals, the serum cytotoxicity was considerable even at 7 days after testicular infarction and this condition was maintained to the 28-day time. Thereafter, cytotoxicity decreased to 3 months and again to 6 months, but even at 6 months, cytotoxicity of serum from Group A animals was still significantly greater than that of controls. 
Table 2. Percentage of spermatozoa dead after treatment with dilutions of sera from rats in Groups A, B and C at each of the 5 experimental times

\begin{tabular}{llccr}
\hline Time & $\begin{array}{c}\text { Serum } \\
\text { dilution }\end{array}$ & $\begin{array}{c}\text { Group A } \\
\text { (ligated) }\end{array}$ & $\begin{array}{c}\text { Group B } \\
\text { (sham- } \\
\text { operated) }\end{array}$ & $\begin{array}{c}\text { Group C } \\
\text { (unoperated) }\end{array}$ \\
\hline \multirow{3}{*}{7 days } & $1 / 3$ & $84 \cdot 4 \pm 7 \cdot 7^{*}$ & $18 \cdot 9 \pm 11 \cdot 4$ & $18 \cdot 3 \pm 6 \cdot 6$ \\
& $1 / 24$ & $87 \cdot 8 \pm 9 \cdot 4^{*}$ & $16 \cdot 1 \pm 5 \cdot 5$ & $11 \cdot 7 \pm 15 \cdot 0$ \\
& $1 / 192$ & $78 \cdot 9 \pm 21 \cdot 9^{*}$ & $9 \cdot 4 \pm 4 \cdot 6$ & $9 \cdot 4 \pm 4 \cdot 6$ \\
14 days & $1 / 3$ & $83 \cdot 9 \pm 12 \cdot 4^{*}$ & $14 \cdot 4 \pm 12 \cdot 1$ & $9 \cdot 4 \pm 5 \cdot 3$ \\
& $1 / 24$ & $80 \cdot 0 \pm 11 \cdot 7^{*}$ & $11 \cdot 7 \pm 6 \cdot 1$ & $8 \cdot 9 \pm 4 \cdot 9$ \\
& $1 / 192$ & $79 \cdot 4 \pm 11 \cdot 6^{*}$ & $10 \cdot 6 \pm 6 \cdot 8$ & $11 \cdot 1 \pm 8 \cdot 9$ \\
& $1 / 3$ & $81 \cdot 5 \pm 12 \cdot 7^{*}$ & $17 \cdot 0 \pm 10 \cdot 3$ & $17 \cdot 0 \pm 8 \cdot 9$ \\
& $1 / 24$ & $77 \cdot 0 \pm 13 \cdot 2^{*}$ & $17 \cdot 5 \pm 12 \cdot 3$ & $10 \cdot 0 \pm 7 \cdot 8$ \\
3 days & $1 / 192$ & $78 \cdot 0 \pm 22 \cdot 5^{*}$ & $13 \cdot 5 \pm 9 \cdot 7$ & $10 \cdot 5 \pm 5 \cdot 5$ \\
& $1 / 3$ & $55 \cdot 0 \pm 26 \cdot 7^{*}$ & $26 \cdot 7 \pm 22 \cdot 2$ & $15 \cdot 0 \pm 8 \cdot 9$ \\
& $1 / 24$ & $53 \cdot 3 \pm 19 \cdot 2^{*}$ & $23 \cdot 9 \pm 19 \cdot 2$ & $13 \cdot 3 \pm 7 \cdot 1$ \\
6 months & $1 / 192$ & $58 \cdot 3 \pm 20 \cdot 0^{*}$ & $11 \cdot 1 \pm 6 \cdot 0$ & $10 \cdot 0 \pm 5 \cdot 0$ \\
& $1 / 3$ & $38 \cdot 9 \pm 28 \cdot 3^{*}$ & $21 \cdot 1 \pm 12 \cdot 7$ & $23 \cdot 3 \pm 22 \cdot 2$ \\
& $1 / 24$ & $35 \cdot 6 \pm 35 \cdot 6^{*}$ & $18 \cdot 3 \pm 18 \cdot 0$ & $15 \cdot 5 \pm 18 \cdot 1$ \\
& $1 / 192$ & $35 \cdot 6 \pm 30 \cdot 9^{*}$ & $12 \cdot 2 \pm 11 \cdot 2$ & $10 \cdot 0 \pm 11 \cdot 4$ \\
\hline
\end{tabular}

Values are mean \pm s.d. for 50 animals in each group.

${ }^{*} P<0.05$ compared with values for Group B and Group C (Student's paired $t$ test and Wilcoxon signed rank test).

\section{Agglutinating antisperm antibody test}

There was no evidence of agglutinating antibody in any of the groups at 7 and 14 days. Some agglutination of spermatozoa occurred after treatment with sera from the Group A animals from the 28-day, 3-month and 6-month post-operative groups. Although the occasional control serum showed minimal agglutination of spermatozoa, this was not a constant feature in any of the control groups.

These are qualitative results; when agglutination was noted the degree to which it occurred varied greatly between individual sera at the 3 times and the agglutination observed was an admixture of the head-to-head and tail-to-tail types.

\section{Serum immunoglobulin assay}

Group A rats showed a significant rise $(P<0.05$; Student's $t$ test $)$ in serum IgM concentrations (mean \pm s.d.) $(124.1 \pm 16.47 \mathrm{mg} / 100 \mathrm{ml}$ compared with $87.4 \pm 14.87 \mathrm{mg} / 100 \mathrm{ml}$ for Groups B and C) and IgG concentrations ( $1252 \pm 714.9 \mathrm{mg} / 100 \mathrm{ml}$ compared with $748.2 \pm 371.6 \mathrm{mg} / 100 \mathrm{ml}$ for Groups B and C) at 7 days. After 14 days, only IgM concentrations were significantly increased $(115.2 \pm 5.9 \mathrm{mg} / 100 \mathrm{ml})$ when compared to levels in the Groups B and C $(93.6 \pm 7.26 \mathrm{mg} / 100 \mathrm{ml})$. Beyond 14 days, immunoglobulin concentrations in Group A rats were similar to those of the controls. IgA concentrations were not significantly altered in any group at any time. There were no significant differences in any immunoglobulin concentrations in the two control groups.

\section{Discussion}

After unilateral ischaemia of the testis in the rat, complex and mainly transient immunological events occur. By 7-14 days after infarction, there is immunocytochemical evidence of antibody 
(predominantly IgM) breaching the 'blood-testis barrier' (Lewis-Jones et al., 1987). Despite the presence of this antibody there is no quantifiable suppression of spermatogenesis, as measured by a Johnsen count, in the 7-14-day post-operative period (Johnsen, 1970; Lewis-Jones \& Kerrigan, 1985). Testicular ischaemia also appears to induce increased serum concentrations of cytotoxic antisperm antibody when compared to control animals, but agglutinating antisperm antibodies, an antibody type often associated with infertility in man, are not produced. Raised concentrations of serum IgG and IgM at 7 days, and IgM at 14 days, suggest that an immune response occurs, but which of the immunological processes described above causes this rise in circulating humoral antibody is unknown.

By 28 days after infarction, antibody penetrating the 'blood-testis barrier' is predominantly of the IgG class (Lewis-Jones et al., 1987) and some suppression of spermatogenesis has occurred. This finding has been reported by other workers (Wallace et al., 1982; Cosentino et al., 1985; York \& Drago, 1985). The degree of suppression noted in this study was not as great as that reported in other investigations in which disruption of tubular architecture, oedema, decreased diameter of seminiferous tubules, spermatocyte and spermatid degeneration, loss of spermatogenesis and sloughing of Sertoli cell cytoplasm have been reported (Cosentino et al., 1985; York \& Drago, 1985). An antibody, apparently directed against the testis, penetrates the 'blood-testis barrier' and affects not only immature spermatogenic cells, but also Sertoli cells. Ultrastructural damage to germ, Sertoli and Leydig cells has also been previously demonstrated (Lewis-Jones et al., 1982). Apparently associated with these intratesticular events, is the continued production of serum antisperm antibodies. Serum cytotoxic antisperm antibody concentrations are maximal at this time interval, and a small number $(20 \%)$ of serum samples showed weak sperm-agglutinating ability (although the technique utilized in this study for detecting agglutinating antibodies was not ideal).

At 3 and 6 months after infarction, several modifications of this immunological process had occurred: Johnsen counts in the ischaemic rats were similar to those of controls, and immunoglobulin breaching the 'blood-testis barrier' was no longer detectable. Cytotoxic antisperm antibody production was progressively waning although, even at the 6-month interval, concentrations, reduced from those measured at 7, 14 and 28 days, were significantly greater than in controls. Despite the semiquantitative method of assessment, agglutinating antisperm antibody was detected at 3 months and this was also present at 6 months after infarction. At 28 days, 3 months and 6 months after infarction, no increases in serum immunoglobulin concentrations were observed when compared to controls, and previously raised concentrations of IgG and IgM, presumably brought about by an initial immune response, had returned to normal levels.

It would appear that unilateral ischaemia of the testis and its epididymis causes the breakdown of sequestration mechanisms which normally prevent presentation of antigens within the genital tract to the immune system. The ischaemic process causes a breakdown of the 'blood-testis barrier' and any immunosuppressive factors in the epididymis are rendered dysfunctional. Antigenic spermatogenic and supportive cells within the testis and epididymis, be they viable or necrotic, are therefore presented to the immune system and thence induce the production of antibodies. The precise locations where antigenic recognition occurs, and the sites of subsequent antibody production, are unknown. Antitestis antibody is able to damage and/or penetrate the 'blood-testis barrier' of the contralateral testis and adversely affect spermatogenesis, either directly or via an effect on Sertoli cells. Antisperm antibody is capable of adversely affecting spermatozoa. This autoimmune phenomenon becomes maximal 28 days after the ischaemic event, but regresses thereafter. This is presumably because production of the antitestis antibody ceases when necrosis of the ipsilateral testis is complete. At 3 and 6 months after infarction, however, there was evidence of the continued presence of cytotoxic and agglutinating antisperm antibodies. Our report of agglutinating antisperm antibody present at 28 days, 3 months and 6 months should be regarded cautiously because rat spermatozoa are not ideally suitable for the agglutinating test used here.

Sympathetic orchiopathia is, therefore, a transient phenomenon resulting in an immunological insult to the male reproductive system. It does not appear to have any long-term deleterious effects 
on sperm maturation. Sympathetic orchiopathia may, however, be one aetiological factor resulting in the production of antisperm antibodies. This might explain why patients with unilateral or bilateral testicular or epididymal infection, disease or damage (e.g. orchitis or epididymitis) have a high incidence of antisperm antibodies (Bandhauer \& Marberger, 1966; Hendry, 1983; Hjort, 1983).

If sympathetic orchiopathia is self limiting, then the suggestion that necrotic testes should be removed to prevent autoimmune damage may have to be reconsidered. The early removal of a necrotic testis (Lewis-Jones et al., 1982; Williamson \& Thomas, 1984), might, unless the testis is completely infarcted, be unnecessary. Similarly, immunosuppression in the post-torsion state may be unnecessary unless long-term antisperm antibody production is proven. Early detorsion, hoping for the retrieval of some spermatogenic cells within the testis, is probably the best form of treatment (Williamson \& Thomas, 1984).

Human post-torsion patients have been demonstrated to be subfertile and oligo-asthenospermic (Krarup, 1978; Bartsch et al., 1980; Chakraborty et al., 1980; Thomas et al., 1984). If torsion does not produce a long-term immunological insult to spermatogenesis in man, then this supports the proposal that torted testes and their contralateral partners may be developmentally abnormal. Such testes may produce an abnormal seminal profile irrespective of whether torsion occurs (Williamson \& Thomas, 1984). The priority in such cases is therefore retrieval and resuscitation of any viable testicular tissue.

\section{References}

Bandhauer, K. \& Marberger, R. (1966) Spermagglutinins in diseases of the epididymis. Excerpta Medica Int. Congr. Series 133, 781-784.

Bartsch, G., Frank, S., Marberger, M. \& Mikuz, G. (1980) Testicular torsion: late results with special regard to fertility and endocrine function. J. Urol. 125, 375-378.

Boyce, E.A., Old, L.J. \& Chouroulinkow, I. (1964) Cytotoxic test for demonstration of mouse antibody. in Methods in Medical Research, Vol. 10, pp. 34-37. Ed. H. N. Elsen. Year Book Medical Publishers Inc., Chicago.

Cerasaro, T.S., Nachtshein, D.A., Otero, F. \& Parsons, C.L. (1984) The effect of testicular torsion on contralateral testis and the production of antisperm antibodies in rabbits. $J$. Urol. 132, 577-579.

Chakraborty, J., Jhunjhunwala, J., Nelson, L. \& Young, M. (1980) Effects of unilateral torsion of the spermatic cord on the contralateral testis in human and guinea pig. Archs Androl. 4, 95-108.

Cosentino, M.J., Nishida, M., Rabinowitz, R. \& Cockett, A.T.K. (1985) Histological changes occurring in the contralateral testes of prepubertal rats subjected to various durations of unilateral spermatic cord torsion. J. Urol. 133, 906-911.

de Kretser, D.M., Temple-Smith, P.D. \& Kerr, J.B. (1982) Anatomical and functional aspects of the male reproductive organs. In Disturbances in Male Fertility, pp. 34-71. Eds K. Bandhauer \& J. Frick. Springer-Verlag, Berlin.

El-Demiry, M.I.M., Hargreave, T.B., Busuttil, A., James, K., Ritchie, A.W.S. \& Chisholm, G.D. (1985) Lymphocyte sub-populations in the male genital tract. $B r$. J. Urol. 57, 769-774.

Friberg, J. (1974) Immunological studies on sperm- agglutinating sera from men. Acta obstet, gynaec. scand., Suppl. 36, 43-50.

Hendry, W.F. (1983) Treatment of antisperm antibodies. In Male Infertility, pp. 280-296. Ed. T. B. Hargreave. Springer-Verlag, Berlin.

Hjort, T.S. (1983) Auto-immunity to sperm. In Male Infertility, pp. 160-187. Ed. T. B. Hargreave. Springer-Verlag, Berlin.

Johnsen, S.G. (1970) Testicular biopsy score count. A method for registration of spermatogenesis in human testes: Normal values and results in 335 hypogonadal males. Hormones 1, 2-25.

Kearney, S.E. \& Lewis-Jones, D.I. (1985) Effect of ACTH on contralateral testicular damage and cytotoxic antisperm antibodies after unilateral testicular ischaemia in the rat. J. Reprod. Fert. 75, 531-535.

Krarup, T. (1978) The testis after torsion. Br.J. Urol. 50, $43-46$.

Lewis-Jones, D.I. \& Kerrigan, D.D. (1985) A modified Johnsen count for evaluating spermatogenesis in the rat. IRCS Med. Sci. 13, 510-511.

Lewis-Jones, D.I., Moreno de Marval, M.J. \& Harrison, R.G. (1982) Impairment of rat spermatogenesis following unilateral experimental ischaemia. Fert. Steril. 38, 482-490.

Lewis-Jones, D.I., Richards, R.C., Lynch, R.V. \& Joughin, E.C. (1987) Immunocytochemical localisation of the antibody which breaches the blood-testis barrier in sympathetic orchiopathia. Br. J. Urol. (in press).

Mancini, G., Carbonara, A. O. \& Heremans, J.F. (1965) Immunochemical quantitation of antigens by single radial immunodiffusion. Immunochemistry $\mathbf{2}$, 235-254.

Nagler, H.M. \& White, R. (1982) The effect of testicular 
torsion on the contralateral testis. J. Urol. 128, 1343-1348.

Ritchie, A.W.S., Hargreave, T.B., James, K. \& Chisholm, G.D. (1984) Intra-epithelial lymphocytes in the normal epididymis. A mechanism for tolerance to sperm auto-antigens? Br. J. Urol. 56, 79-83.

Setchell, B.P. \& Waites, G.M.H. (1975) The blood-testis barrier. In Handbook of Physiology, Endocrinology, Vol. 5, pp. 143-172. Eds D. W. Hamilton \& R. O. Greep. American Physiological Society, Washington, D.C.

Thomas, W.E.G., Cooper, M.J., Smith, J.H.F., Lee, G. \& Williams, R.C.N. (1984) Sympathetic Orchiopathia following acute testicular torsion. Br. J. Surg. 71, 380.
Wallace, D.M.A., Gunter, P.A., Landon, G.V., Pugh, R.C.B. \& Hendry, W.F. (1982) Sympathetic Orchiopathia-An experimental and clinical study. $\mathrm{Br} . J$. Urol. 54, 765-768.

Williamson, R.C.N. \& Thomas, W.E.G. (1984) Sympathetic orchiopathia. Ann. Roy. Coll. Surg. Engl. 66, 264-266.

York, J.P. \& Drago, J.R. (1985) Torsion and the contralateral testicle. J. Urol. 133, 294-297.

Received 22 December 1986 